症例

$$
\text { 術中ェコーにて局在を診断しえたインスリノーマの } 1 \text { 例 }
$$

\begin{tabular}{|c|c|c|c|c|c|c|c|c|c|c|c|}
\hline 須 & 藤 & 峻 & 章1) & 竹 & 本 & 雅 & 彦 & 笠 & 原 & & 洋1) \\
\hline 上 & 田 & 省 & $\equiv^{3)}$ & 菖 & 蒲 & 隆 & 治2) & 中 & 尾 & 稀 & -3) $^{3)}$ \\
\hline 河 & 村 & 正 & 生4) & 梅 & 村 & 博 & $也^{\text {s) }}$ & 白 & 羽 & & 諴6) \\
\hline 久 & 山 & & 健 ${ }^{7}$ & 青 & 木 & 矩 & 彦㖷 & it & 村 & & 次郎 ${ }^{8)}$ \\
\hline 上 & 澤 & 久 & 美8) & 鈴 & 木 & 庯 & $之^{9)}$ & & & & \\
\hline
\end{tabular}

\title{
SUCCESSFUL DIAGNOSIS OF LOCALIZATION OF INSULINOMA BY OPERATIVE ECHOGRAPHY, -A CASE REPORT
}

\author{
Takaaki SUDO, Masahiko TAKEMOTO, Yoh KASAHARA, \\ Shozo UEDA, Ryuji SHOBU, Kiichi NAKAO, \\ Masao KAWAMURA, Hiroya UMEMURA, Sei SHIRAHA, \\ Takashi KUYAMA, Norihiko AOKI, Daijiro TSUJIMURA \\ Kumi UESAWA and Tsuneyuki SUZUKI \\ The Second Department of Surgery, Second internal \\ Medicine and First Department of pathology \\ Kinki University School of Medicine \\ (Director: Pro. Takeshi Kuyama)
}

インスリノーマは, 1-2cm 以下の小さなるのです著明な低血糖発作を起し, 臨床症状 がそろっていてす，いざ手術となると局在馀断をしえない事がある，血管撮影，CT，術 前エュー等の画像診断ならびに経皮経肝門脈採血法があり，経皮経肝門脈採血法は，か なりの実䋶をあげているが，畽瘍の大きさ，数の診断は不可能であり，いま一歩といら 感をまねがれない。

最近私達は，訹中ェコーにて羘体部に $1.3 \times 1.0 \times 0.8 \mathrm{~cm}$ 大のインスリノーマを確認

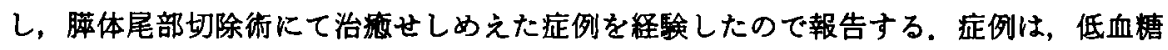
発作を主訴とする58歳男子で，昭和56年 8 月頃より空腹時に心悸九進と頭痛を感してい、 た。昭和57年 9 月頃, 朝食をとらずに眠っていて意識を消失し，某病院内科へ紹介され た，CT，血管撮影，術前エコー，経皮門脈採血によるインスリン浱度を測定し，局在部 位は推測されたが，確認はえられなかった。昭和59年 1 月 9 日，術中ェコーにて䐙体部 Кインスリノーマを確認し, 羘体尾部切除術を施行した。

柬引用語：インスリノーマ, 術中ェュー

\section{I. 緒}

インスリノーマの手術に際して一番重要な事は，局 在診断がなされているかどらかといら事である，血管

1) 医学部講師 2) 助手 3) 研焦医 4) 病完講師

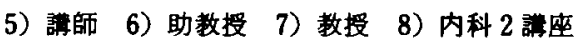

9) 第一病理
撮影, CT 等の検査法では, 1 2cm の小稙焬を発見す る事が困難であったが, 最近経皮経肝採血法で100\%近 く局在診断がなされるよ5になった。しかしながら, 経皮経肝採血法では，畽惖の大きさ，数まで診断する 事は不可能であり，私達は術中ェコーを行い，局在診 断を確実にして羘体尾部切除を行い，治察せしめえた 
症例を経検したので報告する。

II. 症 例

患者：58歳，男性。

主訴：低血糖発作。

既往歴：53歳の時交通事故にて頭部外傷を受け 1 カ 月間入院した事がある.

現病歴：昭和56年 8 月頃空腹時に心悸六進と頭痛を 時ヶ感してていた。昭和57年 9 月頃, 朝食をとらずに眠っ

\section{表 1 術前模查成晴}

\begin{tabular}{lc|ll}
\hline RBC & $421 \times 10^{4} / \mathrm{m}^{3}$ & GOT & 53 \\
Hb & $13.1 \mathrm{~g} / \mathrm{dl}$ & GPT & 69 \\
$\mathrm{Ht}$ & $38.9 \%$ & Al-P & $77 \mathrm{U} / \mathrm{L}$ \\
WBC & $7100 / \mathrm{m}^{3}$ & LOH & $128 \mathrm{U} / \mathrm{L}$ \\
st. & 1 & FBS & $37 \mathrm{mg} / \mathrm{dl}$ \\
seg. & 49 & IRI & $40.2 \mu \mathrm{UU} / \mathrm{ml}$ \\
mono. & 7 & CPR & $2.4 \mathrm{ng} / \mathrm{ml}$ \\
lymph. & 43 & IRG & $120 \mathrm{Pg} / \mathrm{ml}$ \\
T.P. & $8.1 \mathrm{~g} / \mathrm{dl}$ & Elastase & $370 \mathrm{ng} / \mathrm{dl}$ \\
Amylase & $174 \mathrm{I.U}$. & PFD & $75 \%$ \\
Creatinine & $1.2 \mathrm{~m} / \mathrm{dl}$ & Urine & \\
BUN & $14 \mathrm{mg} / \mathrm{dl}$ & Protein & $(-)$ \\
Uric Acid & $7.7 \mathrm{mg} / \mathrm{dl}$ & Sugar & $(-)$ \\
$\mathrm{Na}$ & $149 \mathrm{mEq} / \mathrm{L}$ & Aceton & $(-)$ \\
$\mathrm{K}$ & $3.8 \mathrm{mEq} / \mathrm{L}$ & CPR & $41 \mu \mathrm{gg} /$ day \\
Cl. & $106 \mathrm{mEq} / \mathrm{L}$ & Amylase & $1840 \mathrm{l.U}$. \\
Ca. & $9.5 \mathrm{mg} / \mathrm{dl}$ & & \\
\hline
\end{tabular}

ていて，意識消失をきたし，10日程，某病院に入院し た，退院後も空腹時に手足のしびれ感，視力障害，心 悸六進，振戦，胸部王迫感を覚えることが多かった。 昭和58年 8 月27日再度昼食をとらずにいたため，17時 頃視力障害，胸部圧迫感を 5 ～10分続いた後，意識消 失発作をきたし，脳出血の疑いにて某病院に再入院し， その際，低血糖及びインスリン過鄱分泌を指摘され， インスリノーマの疑いにて当第 2 内科入紹介され，入 院した。入院後諸種検査の後インスリノーマと診断さ れ当外科へ手術のため転科した。

術前検查成嚗（表 1 ）：空腹時血糖値 $37 \mathrm{mg} / \mathrm{dl}$, 血中 インスリン值 $40.2 \mu \mathrm{u} / \mathrm{ml}$ で

$$
\begin{aligned}
& \frac{\mathrm{BS}}{\mathrm{IRI}}=0.92<2.5 \\
& \frac{\mathrm{IRI}}{\mathrm{BS}-30} \times 100=570>200, \\
& \frac{\mathrm{IRI}}{\mathrm{BS}}=1.1>0.5
\end{aligned}
$$

で Grunt ${ }^{1)}$, Turner ${ }^{2)}$ ，大根田 ${ }^{3)}$ のンスリノーマの 判定基準をみたしていた。

空腹時血糖値, 血中インスリン, CPR の日内変動(図 1).

昭和58年10月 5 日 24 時間の日内変動を測定した，空 腹時血糖値は， $45 \mathrm{mg} / \mathrm{dl}$, IRI $41.0 \mu \mathrm{u} / \mathrm{ml}$ で $50 \%$ ド ウ糖 $20 \mathrm{ml}$ 静注後血糖値 $195 \mathrm{mg} / \mathrm{dl}$, IRI $62.1 \mu \mathrm{u} / \mathrm{ml}$ と 增加した。

糖負荷試験（図 2）：糖負荷試験では，空腹時血糖値 は $54 \mathrm{mg} / \mathrm{dl}$, IRI $51.4 \mu \mathrm{u} / \mathrm{ml}$ で, 血桾値は, 30 分 $100 \mathrm{mg} /$

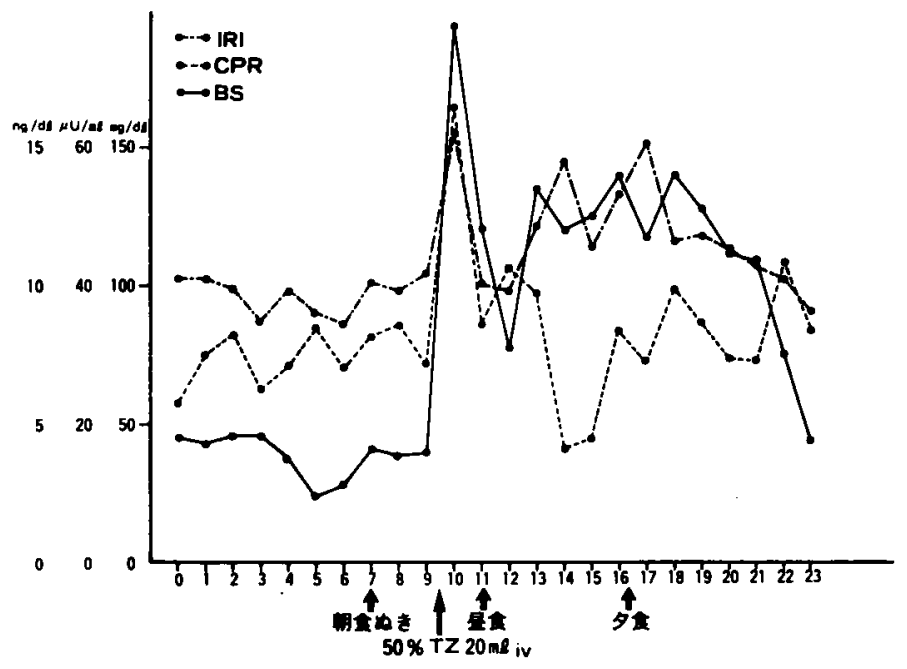

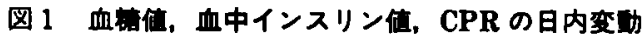




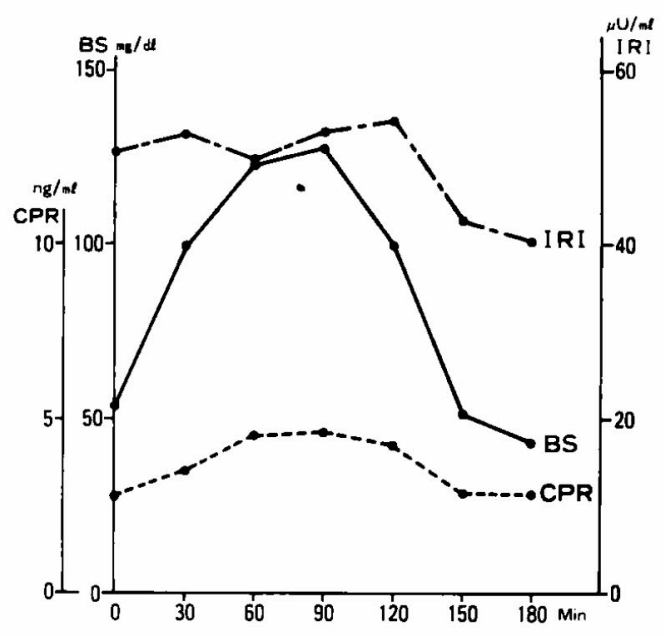

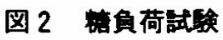

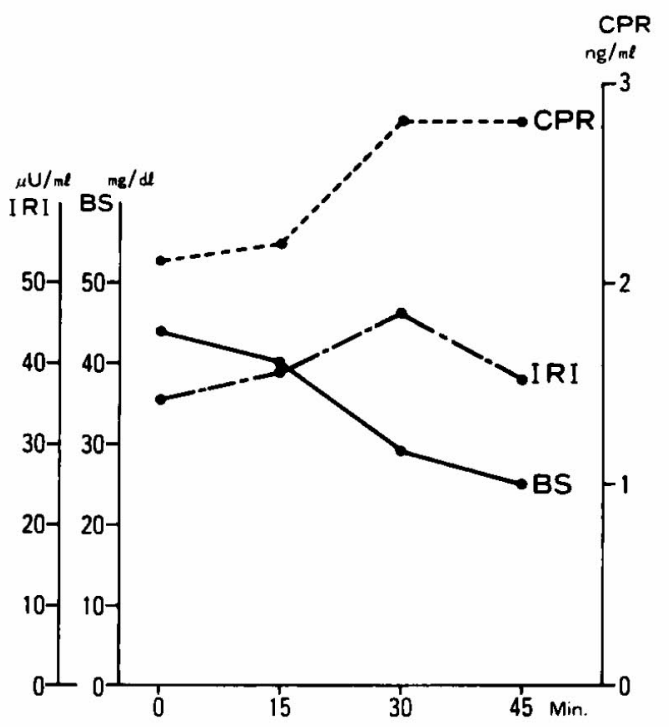

図3ロイシン負荷試碒

$\mathrm{dl}, 60$ 分 $123 \mathrm{mg} / \mathrm{dl} 120$ 分 $100 \mathrm{mg} / \mathrm{dl}$ と推移し，反応性低 血糖は認められなかった。

ロイシン負荷試験（図 3)：空腹時血糖値は，44mg/ $\mathrm{dl}$, IRI $35.2 \mu \mathrm{u} / \mathrm{ml}$, CPR $2.1 \mathrm{mg} / \mathrm{dl}$ で, ロイシン負 荷後, 血糖値は, 15 分 $40 \mathrm{mg} / \mathrm{dl}, 30$ 分 $29 \mathrm{mg} / \mathrm{dl}, 45$ 分 $25 \mathrm{mg} / \mathrm{dl}$ と低下した. IRI は, 15 分 $39.7 \mu \mathrm{u} / \mathrm{ml}, 30$ 分 $46.7 \mu \mathrm{u} / \mathrm{ml}, 45$ 分 $38 \mu \mathrm{u} / \mathrm{ml}$ と推移した.

経皮経肝門脈カテーテル法(図 4, 5)：超音波, CT, 血管撮影にて局在を診断しえなかったので経皮経肝カ テーテル法を試みた。シェーマに示す如く脾静脈 (4)

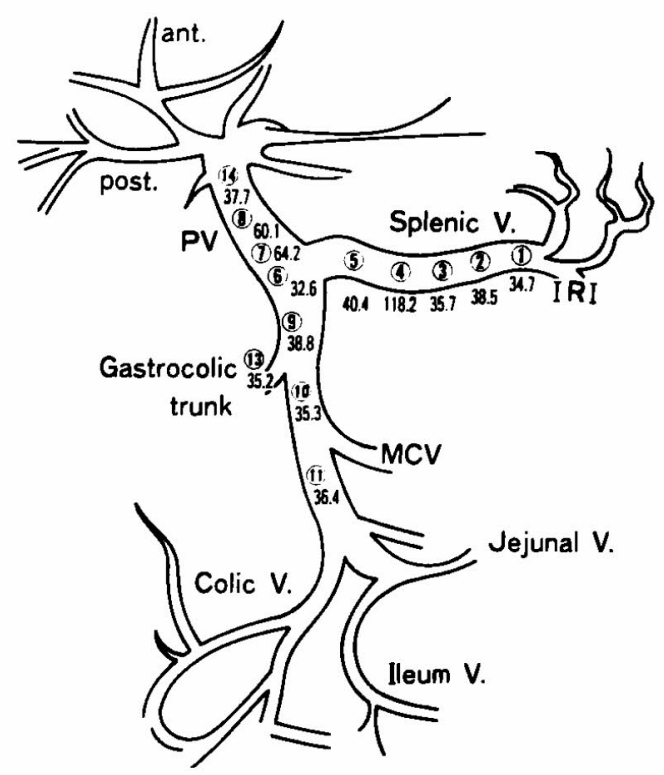

図4経皮経肝阿娦カテーテル法, シエーマ

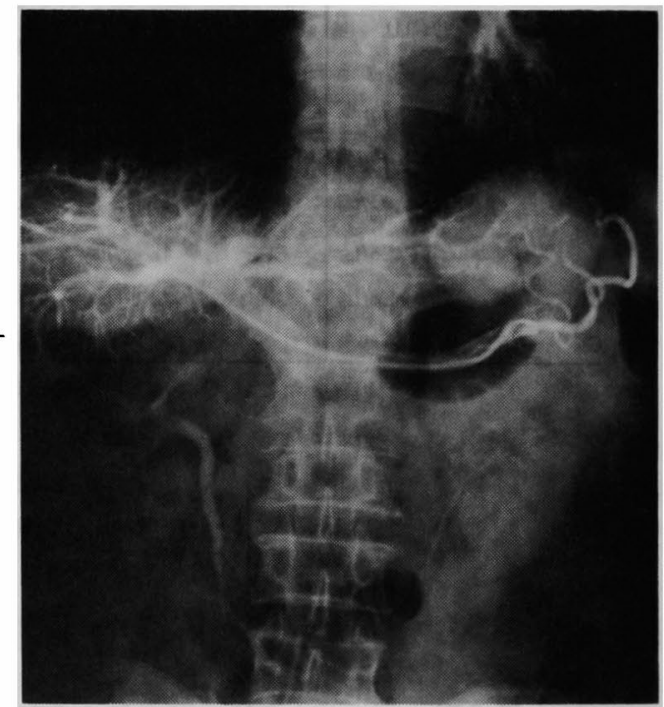

図 5 経皮経肝門脈カテーテル法, レントゲン偍

の部位のインスリン濃度は, $118.2 \mu \mathrm{u} / \mathrm{ml}$ と最高値を 示し，局在が推測された。

手術および術中ェコー：全麻下仰臥位にて上腹部正 中切開にて開腹し, 胃横行結腸間膜を切離し羘体部に 探触子を当て，インスリノーマを探索し，図6に示す 如く小指頭大の腫場陰影を認めたのでその部位を触知 し，インスリノーマを含めて上腸間膜静脈より左側に 


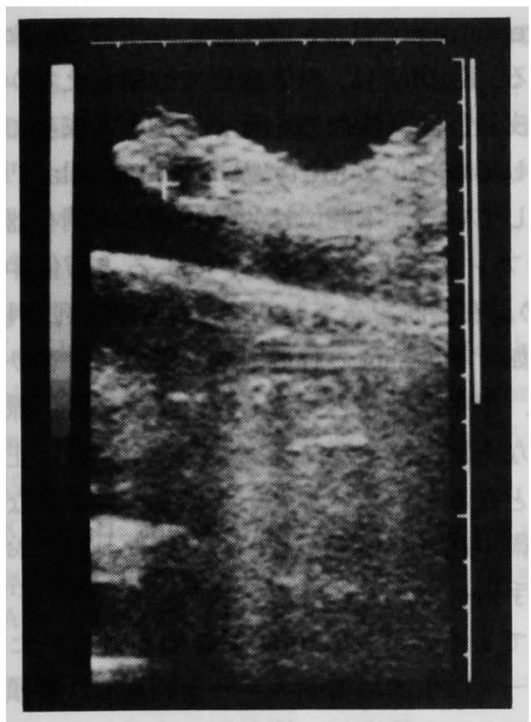

图 6 衍中ェコー

て覀性の事す考虑して蒂体尾部切除術を施行した。

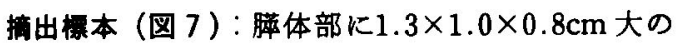
茶褐色のインスリノーマを認めた。

病理組籍学的所見(図 8)：厚い間質結合識にへだて

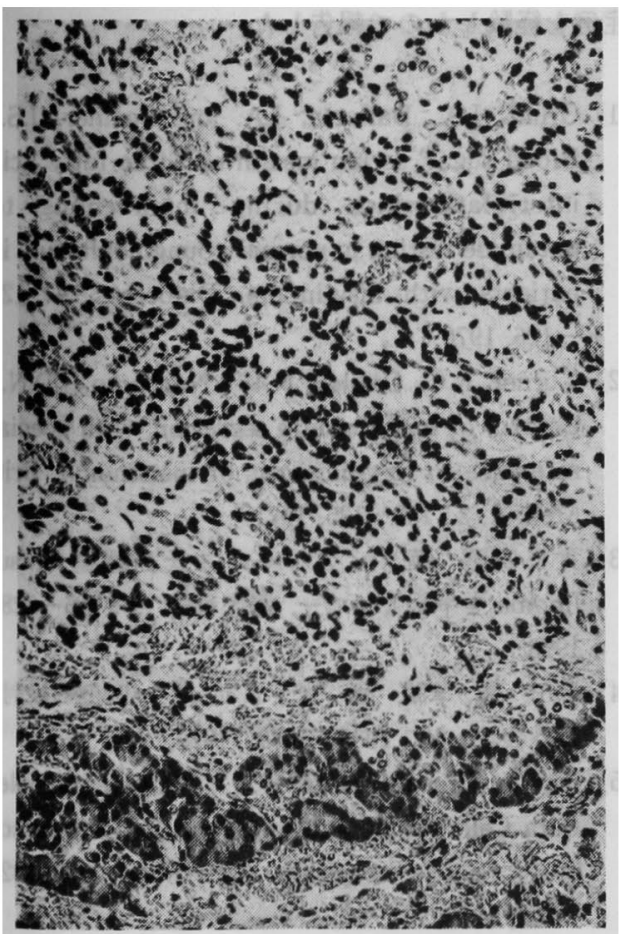

A

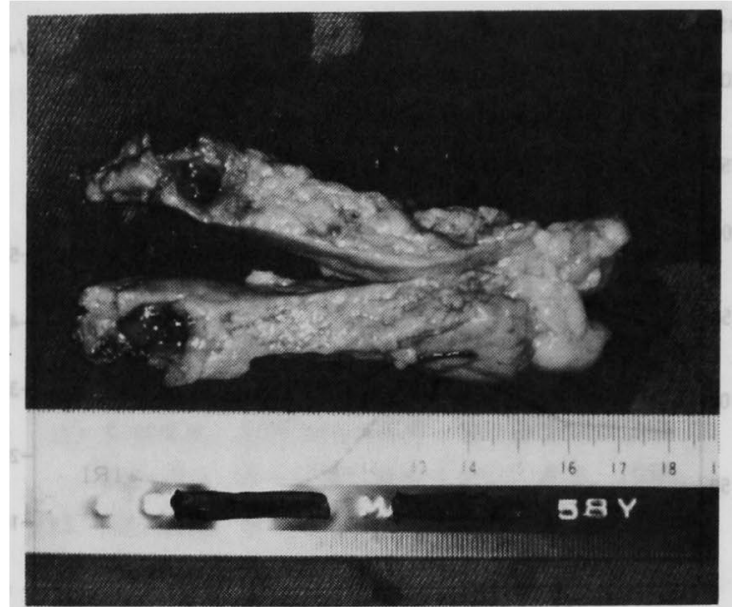

图7インスリノーマ揞止标本

られた小豆大小腫瘤の形成がみられ，畽嫁内には，円 形一棈円形で 1 コのやや大きな核小体とやや粒大なク ロマチンをむつ大小不同性の核とエオシンに濃染し， わずかに顆粒状にみられる胞体をるっており，索状に 増殖しており間質は血管が豊富であった。これらの庫 緆組織の中には，䐙腺房組織の小塊が散在し分化度の

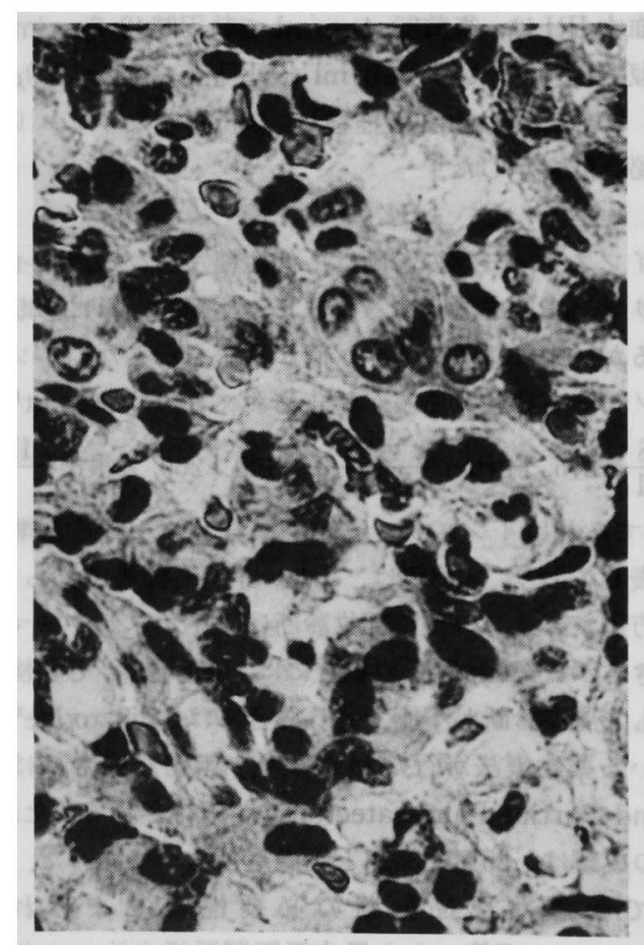

B

图 8 病理組筬学的所見：A. $(\times 10)$ B. $(\times 40)$ 


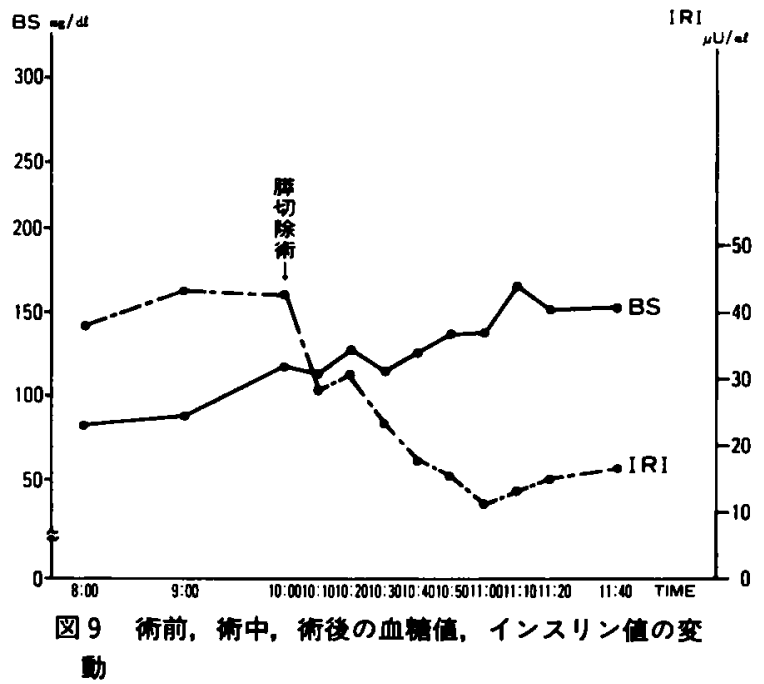

低いインスリノーマと思われたが連続する䐙組織への 浸泟はみられなかった。

術後経過と検查所見（図9)：5\%ブドウ糖を一定速 度で点滴し，術中血糖值，IRI 值のモニターリングを 行った. 術前 $83 \mathrm{mg} / \mathrm{dl}$ で執刃後徐々に増加し, 胼切除 時 $119 \mathrm{mg} / \mathrm{dl}, 70$ 分後 $165 \mathrm{mg} / \mathrm{dl}$ と增加した。

血中 IRI は, 訹前 $38.4 \mu \mathrm{u} / \mathrm{ml}$ で執刃時 $43.6 \mu \mathrm{u} / \mathrm{ml}$, 俩切除後60分で $11.0 \mu \mathrm{u} / \mathrm{ml}$ と低下し，70分 $13.9 \mu \mathrm{u} /$ $\mathrm{ml}, 80$ 分 $12.5 \mu \mathrm{u} / \mathrm{ml}$ と推移し，ほば正常なインスリン 分汼状態を示した。

\section{III. 考 察}

インスリノーマの診断は，低血糖ならびに血中イン スリン，CPR を湘定する事により比軽的簡単に診断さ れるが，中にはインスリン值が高值を示さないインス リノーマす存在する事が報告されており", Grunt ${ }^{11}$ は $\frac{\mathrm{BS}}{\mathrm{IRI}}<2.5$, Turner $^{2)} \frac{\text { IRI }}{\mathrm{BS}-30} \times 100>200$, 大根田 ${ }^{3)} \frac{\text { IRI }}{\mathrm{BS}}>$ 0.5であればインスリノーマであるといら判定基準を 発表しており，本症例は，このいずれる陽性であった。 一方ンスリノーマの部位診断は，インスリノーマの 大きさが1-2cm 以下の場合には，血管撮影， CT 検査 でも，局在診断が不能である場合には，diazoxide 用いる菜物療法が行なわれるが，無奻な場合には， Blind Partial Pancreatectomy が施行されていたが， その成䋶は，25\%ー35\%と不満足なるのであった。 そ こで正確な部位診断の必要性にせまられ, Ingemansson ${ }^{\text {) }}$ 等により経皮経肝門脈採血法によりイ ンスリン濃度を測定し局在診断を行ら方法が開発さ

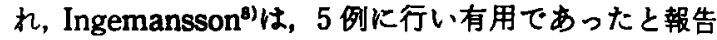
している.Kallioのは，血管撮影で診断しえなかった 4 例に経皮経肝門脈採血法を行い 4 例とも成功であった と報告している. 又 Mitty ${ }^{10)}$ は 2 例を Millan ${ }^{111}$ は 1 例 を報告している，本邦では，第19回日本消化器外科学 会総会フンケート調查報告 ${ }^{12)}$ によると17例中17例， $100 \%$ 局在診断をえており，又私達の症例でも，図 4 に示す如く 4 の部位の脾静脈が最高のインスリン灌度 を示し，術中の局在と一致した，释皮経肝門脈採血法 は有用な万法であるが，腫楊の大きさ，数，正確な占 拠部位となるといま一步といら感をすぬがれない。

最近術中契音波検査がさかんに行なわれており，肝 澸癌の手術にさかんに応用されている。幕内等 ${ }^{(3)}$ は，血 管撮影です tumor steining が認められていたがイン スリノーマの手術に術中ェューを利用し，茀頭部にイ ンスリノーマを描出し，核出術に成功したと報告して いる. 私達の症例では，血管撮影，CT，術前超音波検 査で tumor steining が認められなかったりのであり， 術中エコーが非常に有効な症例であった。

\section{IV. 結 語}

経皮释肝門脈カテーテル採血法ならびに術中ェコー にて局在診断を行い苹体尾部切除術にて治蒠せしめえ た症例を経験したので報告した。

\section{文献}

1) Grunt, J.A., Dallotta, J.A. and Soelner, J.S. : Blood sugar, serum insulin and free fatty acid interrelationships during intravenous to butamide testing in normal young adults and in patients with insulinoma. Diabetes, 19: 122 $-126,1970$.

2) Turner, R.C., Oakley, N.W., Narbarro, J.D.N.: Control of basal insulin secretion, with special reference to the diagnosis of insulinoma. Brit. Med. J., 2 : 132-135, 1971.

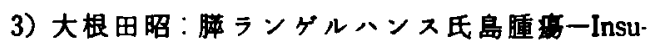
linomaを中心として一, 臨床科学, 9:716-728, 1973.

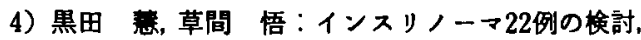
日外会誌, $80 ： 1035-1039,1979$.

5) Kavlie, H. and White, T.T.: Pancreatic islet Beta Cell Tumor and hyperplasia : Experience in 14 Seattle hospitals. Ann. Surg., 175: 326 $-355,1972$.

6) Mengoli, L. and Lequesne, L.P.: Blind pancreatic resection for suspected insulinoma: $\mathbf{A}$ 
review of the problem. Brit. J. Surg., $54: 749$ $-756,1967$.

7) Stefanini, P., Carboni, M., Patrassi, N., et al. : The surgical treatment of occult insulinomas: A review of the problem. Brit. J. Surg., $61: 1-4$, 1974.

8) Ingemansson, S., Kuhi, C., Larsson, L.I., etal. : Localization of insulinomas an islet cell hyperplasia by pancreatic vein catheterization and insulin assay. Surg. Gyne. Obst., 146: 725-734, 1978.

9) Kallio, H. and Svoranta, H.: Loealization of occult insulin secreting tunors of the pancreas. Ann. Surg , $189: 49-52.1979$.
10) Mitty, H.A., Efremidis, S., Wertkin, M.G., et al. : Localization of insulinomas by radioimmunoassay of blood obtained by the transportal route. J. Clin. Endo. Met., 48 : 1035-1037, 1979.

11) Millan, C.G., Urosa, C.L., Molitch, M.E., et al. : Localization of occult insulinomas by super selection pancreatic venous sampling for insulin assay through percutaneous transhepatic catheterization: Diabetes, $28: 249-251,1979$.

12）中村卓次，笹野伸昭，黒田慧：羘島細胞腫䓪 259-265, 医学図書出版株式会社, 東京, 1978.

13）真内雅敏，長谷川博，山䗁 晋他：術中超音波検 㚗, 外科治療, $48 ： 1979-207 ， 1983$. 